\title{
Design and Implementation of an Electronic Document Management System
}

\author{
Arkan Mahmood ${ }^{1 *}$, Ibrahim Taner Okumus² \\ "Kahramanmaras Sutcu Imam University, Graduate School of Natural and Applied Sciences \\ ${ }^{2}$ Assoc. Prof. Dr., Kahramanmaras Sutcu Imam University, Computer Engineering
}

Geliș Tarihi/Received: 13.06.2017

Kabul Tarihi/Accepted: 03.08.2017

Araștırma Makalesi/Research Article

\section{ÖZET}

Günümüzde gelișmekte olan ülkelerin birçoğunda geleneksel kağıt belge yönetimi yapılmaktadır ancak e-posta, web sayfaları ve veritabanları gibi bilgisayarlarda ve sunucularda depolanan elektronik dökümantasyon biçimleri de yaygınlașmaktadır. Bir eğitim kurumunda ya da ișletmelerde bütünleșik veri toplama ișlemi için elektronik belge yönetim sistemi (EBYS) yönetim için en gerekli araçlardan birisi haline gelmektedir. Ancak bu gereklilik kurumun ya da ișletmenin intiyacı doğrultusunda dikkatli bir biçimde gerçeklenmelidir. Bu nedenle kurum, bünyesindeki verileri olușturmak, saklamak ve düzenlemek ve tüm senkronizasyon süreçlerini yönetmek için EBYS kullanmalıdır. $\mathrm{Bu}$ araștırmada bir politeknik üniversitesinin bilgisayar bilimleri enstitüsü için system gereksinimleri analizi, yazılım tasarımı ve kullanılabilir kaynak tespiti yapıldı ve masaüstü tabanlı bir uygulama geliștirilerek bașarılı bir șekilde gerçeklendi. Diğer EBYS sistemlerinden farklı olarak dışarıdan gelen belgeler için bir döküman notasyonu eklendi, mevcut e-imze tekniği değiștirildi ve güvenlik seviyesini arttırmak için yeni özellikler eklendi. İlave olarak arșivlenen dosyaların güvenliği, belgelerin içeriklerinin takibi yapılarak arttııldı. Son olarak yazılım kurum intiyaçlarına gore özelleștirildi ve system yöneticisinin taleplerine gore değiștirilebilir şekilde tasarlandı.

\section{Anahtar kelimeler}

EBYS, Güvenlik, Yönetim, Yazılım, Elektronik İmza

* Sorumlu yazar/Corresponding author E-mail/e-ileti: arkanismael83@yahoo.com

\begin{abstract}
Nowadays most of the developing countries use traditional paper documents management system (DMS), but also the electronic form of the documentation has increased including e-mails, web pages, and database packages, which have been stored in workstations and servers. For integrated data gathering in an institution or organization, electronic document management system (EDMS) often becomes one of the most required tools for management. However, this requirement should be implemented carefully depending on the institution or organization need. Therefore, organization should have an EDMS for creating, keeping and organizing data in the organization and handle all synchronization process.

In this research, system requirements for computer science institution of polytechnic university is analyzed, software design and identifying available resources is determined and a desktop based application is developed and implemented successfully. Distinguishing the developed EDMS from other management systems is that it adds document notation for external documents and existing digital signature technique has been modified and new features added for improving security level. In addition, security of archived files is increased by monitoring the contents of the documents. Finally, institution structure is customized and can be modified based on the system administrator's request.
\end{abstract}

\section{Keywords}

Keywords: EDMS, Security, Management, Software, Digital Signature. 


\section{INTRODUCTION}

Today, document management systems support the life cycle management of document based information. Researchers worldwide have conducted many studies in order to evaluate traditional document management system (DMS) and electronic document management systems (EDMS) (Anderson, 2012; Noyes and Garland, 2008) in terms of user performance and showed advantages of newly developed electronic systems.

As new technologies have been emerged, organizations have moved from traditional DMS to an electronic form of DMS since it facilitates the managerial work through file integration and control. Based on the previous studies, an electronic DMS provides many advantages including management support, budgetary, Security, Cooperation, performance, privacy and Systems integration (Abdulkadhim et al., 2015). Therefore, in order to have a good management and administration system, every organization should adopt an electronic DMS.

Considering general requirements of an Electronic DMS, the designed system in this study have three major characteristics. - Management: three main features have been added to this system in order to facilitate the work of users. They can easily retrieve files in a short amount of time and also can search required files using many criteria. Moreover, the performance of this system is increased by adopting some techniques while users process data.

- Security: Digital signature has been used for controlling user's access and document validation. In this system the identity of the creator as well as the users of a digital content is captured and stored with the digital content for ensuring nonrepudiation and history information about the digital content.

- Control: various control procedures have been applied to control user, document, data, access, backup and restore.

The aim of the study is to design and develop a DMS application that can be used by organizations in order to move from traditional system to an organized and cost saving electronic system.

\section{RELATED STUDY}

EDMS can be defined as a group of information containing various type of documents that may exist in different places within a network and support multiple access, update and modification simultaneously and automatically (Asogwa,2012; Ostroukh,2014). EDMS have been applied in different organizations across the world. It has helped organizations to be successful in terms of management strategy, budgetary, anti-corruption, security and privacy, user requirements, cooperation and systems integration (Abdulkadhim et al, 2015) (Singh et al., 2007). Moreover, Alshibly(2016) and Vevaina(2007) indicated that EDMS can be used to help organizations to achieve more efficient operations by reducing transaction costs, automating processes, improving capacity, minimizing errors, and saving on labor.

EDMS have been used in governmental and public organizations. EDMS implementation studies in government sector began to grow in the early 2000s (J. McLeod, and C. Hare,2010). For the purpose of providing productivity, space saving and a general improvement in business processes, government organizations are increasingly 
implementing EDMS in order to transform service delivery within the organizations and to citizens (Adam, 2008; Hung et al., 2009; Cimtech, 2007). In addition, Applying EDMS in governments can be used to reduce operating costs and minimize office space for filing and reducing the cost of labor (Grange and Scott, 2010).

Wicaksono(2015) have conducted a study and developed a web based application for managing documents in higher education environment. He suggests a thorough system requirement process and high level management should be involved in tackling user's acceptance of EDMS systems. In addition, Hwang et al.(2013) concluded that most institutes consider document standardization to be very important in which $76 \%$ of institutes (19 out of 25) answered that a systematic document management system was necessary. Moreover, due to the capabilities of EDMS in creating, saving, distributing, archiving, and accessing the documents by searching according to desired criteria, Yaldır and Polat(2016) stated that applying an EDMS for university is very important. In term of security, most of the papers have not mentioned any specific technique to provide a security level for the system. The proposed EDMS system in this study differs from the other EDMS systems since various security levels have been applied. This system uses digital signature besides the basic authorization technique that asks for a username and password in order to login to the system. Every user that has manager permission should use a digital signature in order to send files to other departments. The digital signature is applied by using a hardware that contains username, password and serial of the hardware. When a manager tries to send a document, the system checks the hardware as well as the username and password of the manager.

\subsection{The Use of EDMS in Education Sector}

Özdemirci(2008) indicated that electronic document management system is crucial for education institutions. He carried a study in order to analyze records management and archive processes in Ankara University. As a result, a model for all universities in turkey is proposed in order to execute the records and archive processes according to the principles and methods of records and archives management. The proposed model of Özdemirci(2008) have been taken into consideration in developing the application for polytechnic institution and new features have been added.

Moreover, Basibuyuk(2015) have developed an application for Kırıkkale University that can be accessed twenty four hours through EDMS's web-based infrastructure. The developed system can be accessed from inside-outside of the university using any mobile device which has internet access such as PC, laptop, tablet. However, security for documents in the system has not been provided and digital signature is recommended. This lack of security has been solved as a part of the application developed for polytechnic institution in which digital signature has been used.

\section{SYSTEM ARCHITECTURE}

In order to design an effective EDMS that can be applied to an educational institution, previous studies have been analyzed and various ideas have been combined. Moreover, organizational needs and new ideas have been considered for the design of the developed system. 
For the requirement gathering and data analysis phase, many people have been interviewed in different organizations and existing documents of those organizations have been considered for the analysis and designing of the new system.

The developed desktop application for computer science institution of polytechnic university is implemented and has been used by 30 users in 12 departments. The system is developed based on predefined requirements of the employees and managers in the institution. Therefore new features have been added and some existing features of the popular EDMSs have been modified based on the user request.

\subsection{Document Management}

Fig.(1) shows the design of the proposed EDMS system. The system is divided into three modules including document management, document storage and document retrieval and sharing.

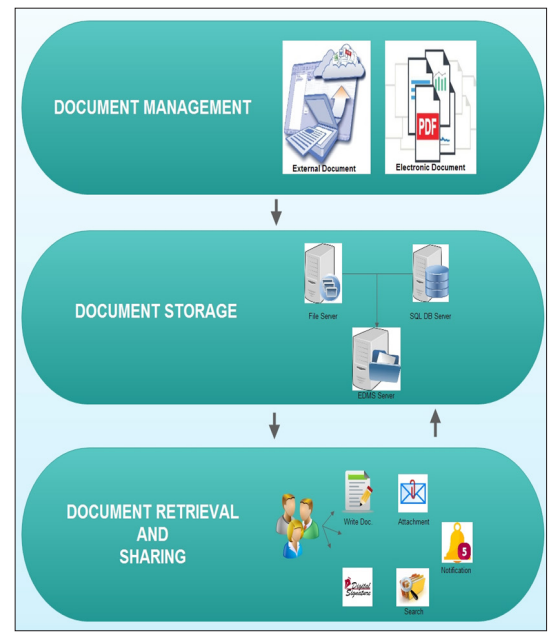

Figure1. Proposed EDMS architecture.
- Document management: in the developed system, documents are managed in two ways.

o External documents that are in a form of hard copy will be scanned and imported into the system. The reason behind this idea is to manage the documents that may come from an external organization that have not still transformed to an electronic system. The external documents is first received by the dean then will be sent to other departments. In this system, a new feature is added called document notation which will help the dean to share documents with all departments without creating a new document to explain the received external document.

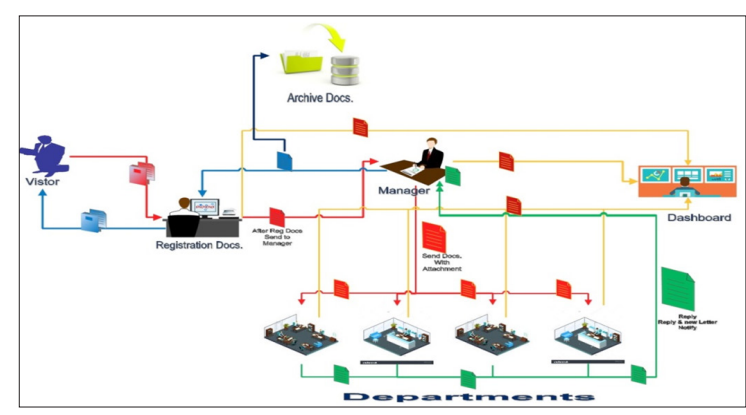

Figure 2. External document management

o Internal documents can still be created by system users. After the created document is saved and archived, the content of the document will be saved in a table which it can be used later to check whether the document have been modified by unauthorized users.

- Document storage: In this system, two servers have been used for storing documents. File server is used to store files that have been either captured or created by a system user in a form of PDF type. The reason behind using this server is to increase system security and 
archiving; while, database server is used to store system data and operate the entire system.

- Document Retrieval and sharing: In this system, users are able to perform various actions including writing, searching, sending, editing, reporting, attaching, routing and approval of documents.

\subsection{User Management}

The User Management System provides functionality to manage user profile. It implements user authentication and provides classification. User profiles contain information such as user identification number, email, first and last name, etc. In order to access user profile for reading and modification, user ID is used for authentication. User information contains user identification number, username, password and session for authentication.

Fig (3). Shows the user Management and their functionalities in the system. In the proposed system user management involves the following properties:

- Add Users: This system has three types of users: administrator, manager and secretary. Each of them is responsible for specific actions based on the permissions provided. Administrators are able to add new users to join their organization's department. New users can be either manager or secretary for a department.

- Manage Users: Existing users can be edited or deleted at any point in time.

- Access permissions:

User permissions depend on the type of user and the department they belong to. Different permissions have been assigned to the types of user based on their responsibilities

- User security: two levels of security have been applied for each user. The first level is user authentication which is provided by usernames and password for accessing the system. The second level is the combination of user authentication as well as an external hardware for the users that are authorized to have electronic signature.

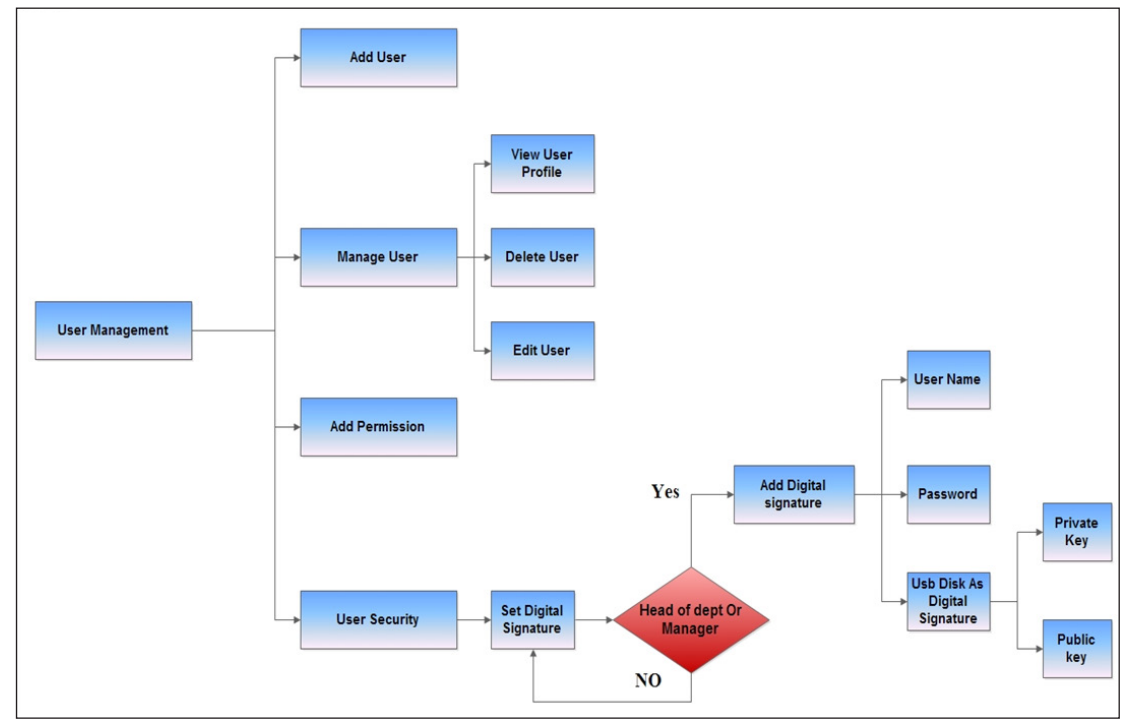

Figure 3. User management flowchart 
The popular feature of electronic signature is modified in the developed system by using a special USB drive that contain unique serial and a key. The unique code will be attached to the sent document every time the drive is used by managers or head of departments. This code is working instead of a stamp which was used in the institution.

\section{IMPLEMENTATION AND TESTING}

This chapter presents the actual implementation of the system and shows various functionalities that can be useful for any educational institution moving from a traditional paper based system to an EDMS.

When a manager authorized to access the system, he/she will have three main features including note, internal document and incoming document. Notation is used so that users can comment on a specific document to express their ideas while internal document option displays all the documents that have been created inside the organization. In addition, incoming document feature displays all the documents that have been received from external organizations. On the other hand, a normal user will have access to note and internal document.

\subsection{Document Handling Procedures}

This system handles the documents in two ways: hard copy document processing and new document creation.

\subsubsection{Hard copy documents (External documents)}

Figure (4) shows the procedure of External Document Registrations This type of document comes from outside the organization, the hard copy document passes through some procedures including document scanning which directly converts the document into a PDF format file and gets document details such as (document number, title, issue date, issuer name). Before saving the file, a new document ID and registration date will be given to the scanned document and will be sent to the manager.

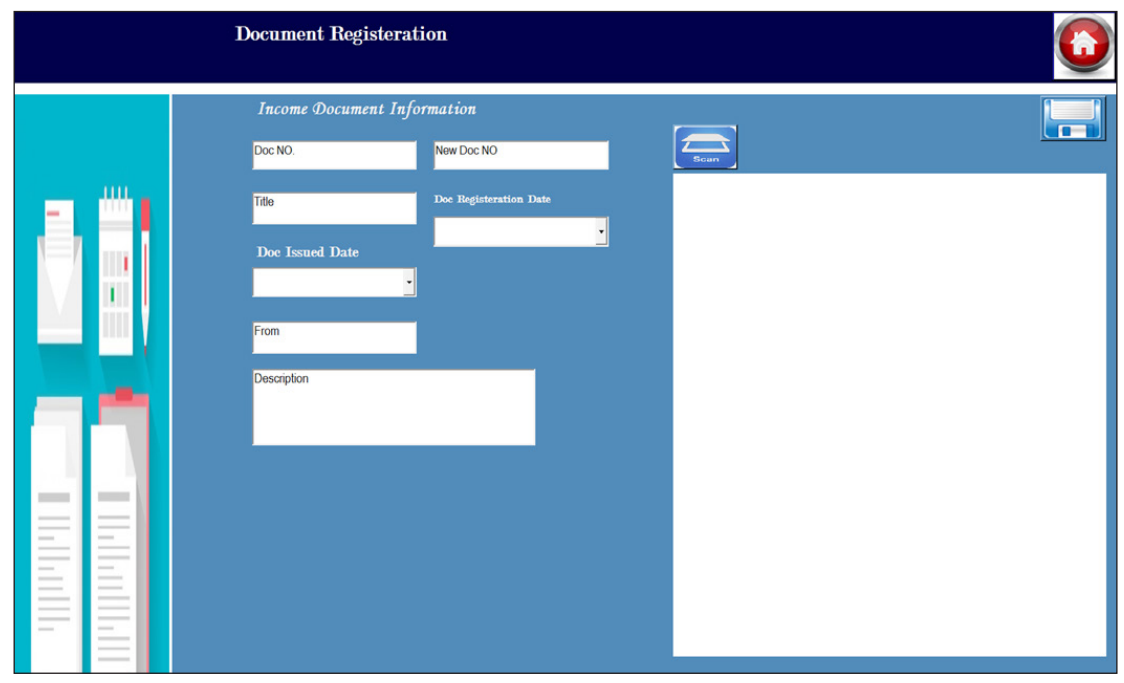

Figure 4. External document registrations. 


\subsubsection{New document creation (Internal documents)}

Figure (5) shows the procedure of new document creation. Every department in the system can create new documents inside the organization and this is performed by only head of departments and department secretary. Every new document has the following parameters: Document Number, to, document type, title, date and the content. After filling the details of the new document, users can view a sample MS-word template of the document. Showing the view option in an MS-word document eases the editing functionality of the document. If no change is required, users can directly send the newly created document to the departments and in this sending option the MS-word documents will be converted into a PDF file.

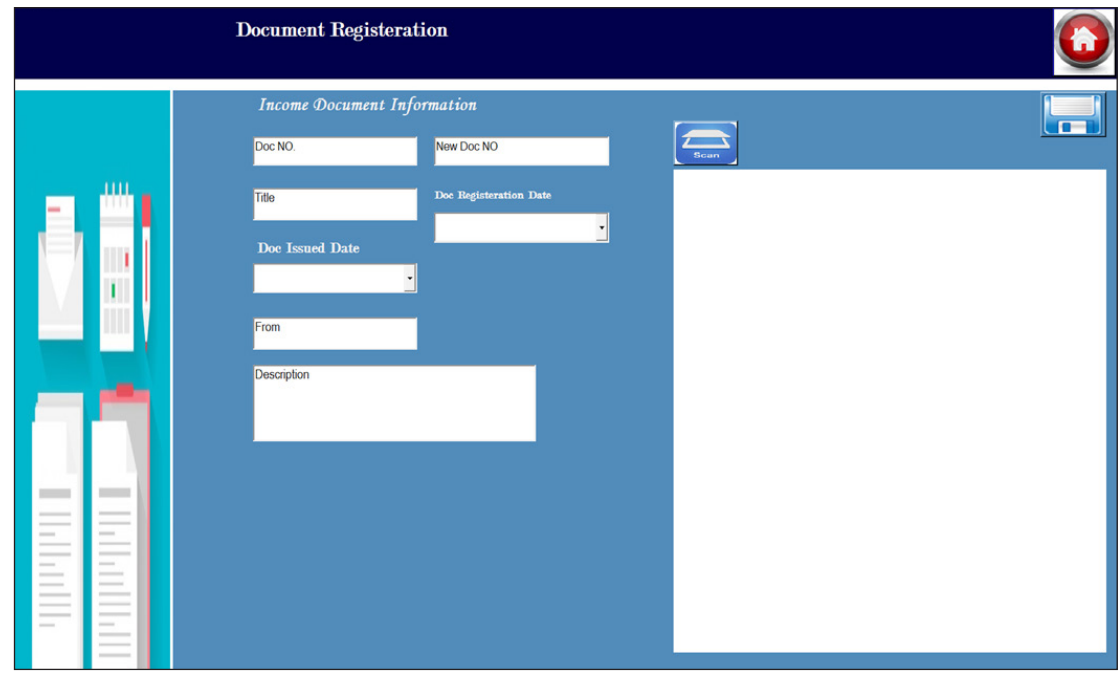

Figure 5. New document creation.

\subsection{Using Digital Signature for Sending Documents}

In this system, sending documents require some verification in which only head of the departments has this permission. The system verifies user permission by checking user name, password which is different from the user name and password for login. Moreover, each head of department must have a USB disk that contains public and private keys which can be used for digitally signing files before sending. Therefore, the system security is provided via digital signatures using a hardware and user authentication method.

\subsection{Manage Departments}

The relation of departments in the system can be determined by the administrator according to the structure of the organization. The procedure behind creating relation between these departments is applied by loading each department and specifies relationship.

\subsection{Dashboard for Document Search}

In this system, a dashboard is created so that users can check all documents including seen, non-seen, created and received files. This dashboard ensures that 
after a file is seen by the user, it will be out of reach for modification. In Addition, the document registration manager can check whether document processes have been finished or not.

\subsection{Advantages and Disadvantages of The Developed System}

The developed system provides many advantages for computer science institution of polytechnic university. Firstly, it is specifically designed to fulfill the institution requirement. Secondly, the management structure can be redesigned based on the changes required by managers without the help of the software developer. Thirdly, the developed system is user friendly and can be adopted by any educational institution. Finally, it provides many other features that are common in every EDMS including search, cost savings, reliability, increased document security using digital signature, control, archiving and cooperation.

However, the developed system has some shortcomings. It is only designed for managing documents; it does not contain any functionality for student and employee information management. Moreover, this system does not support email and message facility from outside the system.

\section{CONCLUSION}

Moving from a traditional paper work system to an Electronic Document Management system helps educational institutions to reduce costs, automating processes increased document security and minimizing errors. This article shows the implementation of a document management system that is specifically designed for an educational institution based on their requirement. The developed EDMS provide users in the institution with a simple and efficient mechanism to access, manage and share their documents using new techniques and modifying some features in security and management. The system enables users to manipulate, share, synchronize and considers the support of heterogeneous client devices. Moreover, every action in the system will be audited. Finally, archiving in the system is performed by saving the document data in the SQL server and save the documents as a PDF file in the file server. This functionality ensures data integrity and prevents data loss. This application can be further extended by adding new sections including human resources, versioning and student registration. In addition, the hardware used for digital signature can also be used as an identity for the users of the system containing all user information. 


\section{REFERENCES}

Abdulkadhim, H., Bahari, M., Bakri, A., \& Ismail, W. (2015). A research framework of electronic document management systems (edms) implementatıon process in government. Journal of Theoretical and Applied Information Technology, 81(3), 420.

Adam, A. (2008). Implementing electronic document and record management systems. 1st Edn, New York: Auerbach Publications.

Anderson, C. (2012). Is document control really that important? Bizmanualz OnPolic. Retrieved September 23, 2012, From http://www.onpolicy. com/2010-12/is-document-control-really-thatimportant.html.

Asogwa, B. E. (2012). The challenge of managing electronic records in developing countries: implications for records managers in sub saharan africa, Records Management Journal, 22, 198-211.

Bașıüyük, M. (2015). Electronic document management system for Kırıkkale University. Unified Journal of Computer Science Research, 1(2), 8-15, From http://www.unifiedjournals.org/ ujcsr .

Cimtech. (2007). Managing information and documents: The definitive guide, 18th Edn.. London: Information 537 Age

Grange, M. \& Scott, M. (2010). An Investigation into the affect of poor end user involvement on electronic 547 document management system (EDMS) implementation. 15th Annual Conference In: UK Academy for Information Systems (UKAIS) 548, Oriel College, Oxford.

Haitham, A., Chiong, R. \& Bao, Y. (2016). Investigating the critical success factors for Implementing electronic document management systems in governments. Information Systems Management · DOI:10.1080/10580530.2016.1220 213.

Hung, S., King-Zoo, T., Chia-Ming C., \& Ching-De K. (2009). User acceptance of intergovernmental 567 services: An example of electronic document management system. Government Information Quarterly, 568 26(4), 387-397.
Hwang, S. H., Jung, S. K., Kang, S. J., Cha, H. S., Chung, S. H., \& Lee, D. H. (2013). Development of a Document Management System for the Standardization of Clinical Laboratory Documents. Annals of Laboratory Medicine · DOI: 10.3343/alm.2013.33.6.441. From: https://www. researchgate.net/publication/258351497.

J. McLeod., and C. Hare.(2010). Development of RMJ: A mirror of the development of the profession and discipline of records management. Records Management Journal, 20(1), 2010, 9-40. Noyes, J. M.,\& Garland, K. J. (2008). Computervs. paper-based tasks: Are they equivalent?, Ergonomics, 51(9), 1352-1375.

Ostroukh, A., Krasnyanskiy, M., Karpushkin S. \&Obukhov, A. (2014, December). Development of automated control system for university research projects. Middle-East Journal of Scientific Research, 20(12), 2014, pp.1780-1784. From www. idosi.org/mejsr/mejsr20(12)14/15.pdf .

Özdemirci, F. (2008). Development and implementation of the document management and archiving system (BEYAS) for universities: an example of cooperation, 225-235

Singh, P., Klobas, J., \& Anderson, K. (2007). Information seeking behavior of electronic records management systems (ERMS) users: Implications for records management practices part 1. Informaa Quarterly, 23(4), 38-41.

Vevaina, P. (2007). Factors affecting the implementation of enterprise systems within government organizations in New Zealand. Master's thesis, Auckland University of Technology, New Zealand.

Wicaksono. (2015). Implementing collaborative document management system in higher education environment. issn 2089-1083 snatika 2015, volume 03.

Yaldır, A. \& Polat, L. Ö. (2016). Electronic document management system selection with multi-criteria decision making techniques. Mehmet Akif Ersoy Üniversitesi Sosyal Bilimler Enstitüsü Dergisi. 8(14), 88-108. issn:1309-1387 